\title{
Oil and Gas Industries in India- A Case Study
}

\author{
Jayameena Desikan ${ }^{1}$, \& A. Jayanthila Devi ${ }^{2}$ \\ Research Scholar, College of Computer Science and Information Science, Srinivas \\ University, Mangalore-575001, India. \\ Orcid ID: 0000-0003-4592-2722; E-mail:meethu_8@yahoo.com \\ ${ }^{2}$ Research Professor, College of Computer Science and Information Science, Srinivas \\ University, Mangalore - 575001, India \\ Orcid ID: 0000-0002-6023-3899; E-mail: drjayanthila@gmail.com
}

Area of the Paper: Information Management.

Type of the Paper: Case Study.

Type of Review: Peer Reviewed as per $|\mathrm{C}| \mathrm{O}|\mathrm{P}| \mathrm{E} \mid$ guidance.

Indexed In: OpenAIRE.

DOI: https://doi.org/10.5281/zenodo.6180214

Google Scholar Citation: IJCSBE

\section{How to Cite this Paper:}

Jayameena Desikan \& Jayanthila Devi, A., (2022). Oil and Gas Industries in India- A Case Study. International Journal of Case Studies in Business, IT, and Education (IJCSBE), 6(1), 110-125. DOI: https://doi.org/10.5281/zenodo.6180214

International Journal of Case Studies in Business, IT and Education (IJCSBE)

A Refereed International Journal of Srinivas University, India.

Crossref DOI : https://doi.org/10.47992/IJCSBE.2581.6942.0154

(C) With Authors.

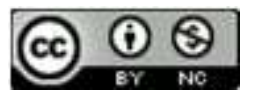

This work is licensed under a Creative Commons Attribution Non-Commercial 4.0 International License subject to proper citation to the publication source of the work.

Disclaimer: The scholarly papers as reviewed and published by the Srinivas Publications (S.P.), India are the views and opinions of their respective authors and are not the views or opinions of the S.P. The S.P. disclaims of any harm or loss caused due to the published content to any party. 


\title{
Oil and Gas Industries in India- A Case Study
}

\author{
Jayameena Desikan ${ }^{1}$, \& A. Jayanthila Devi ${ }^{2}$ \\ ${ }^{1}$ Research Scholar, College of Computer Science and Information Science, Srinivas \\ University, Mangalore- 575001, India. \\ Orcid ID: 0000-0003-4592-2722; E-mail:meethu_8@yahoo.com \\ ${ }^{2}$ Research Professor, College of Computer Science and Information Science, Srinivas \\ University, Mangalore - 575001, India \\ Orcid ID: 0000-0002-6023-3899; E-mail: drjayanthila@gmail.com
}

\begin{abstract}
Purpose: The petroleum industry is one of the India's core industries, and it has a significant impact on decision-making in the critical sectors of the India's economy. Oil and Natural Gas Industries occupies the core in the world's energy market. These enterprises assumes a significant part in each nation's economy and monetary development of India is firmly connected with its energy interest. Investment in this industry is continuously increasing as the energy demand is also continuously increasing in India. This paper will discuss and analyze about the Oil and Gas Industries of India related to multiple factors impacting these industries which includes technological trends, innovations, corporate social responsibility, research and development, Covid-19 impact and its related economic impact.

Design/Methodology/Approach: Oil and Gas Industries are chosen and in depth analysis done by getting data from websites, journal, articles and blogs. Focused on Industry related objects, studied, evaluated and compared various points related to oil and gas industries.

Findings/Result: Oil and Gas Industries are analyzed by understanding and studying the different aspects of these industries. Indian monetary development is additionally affected due to these businesses. Alternatives to Oil and Natural Gas, technological innovations and research and development as recommendations are also discussed and suggested.
\end{abstract}

Originality/Value: Oil and Gas Industries data from different sources studied and documented.

Paper Type: Case study analysis.

Keywords: Oil and Gas Industry, Upstream, Downstream, Midstream, CSR, Innovations, Covid19 impact, SWOC analysis.

\section{INTRODUCTION :}

The country's first oil resources were discovered during 1889 near the city of Digboi in Assam. The discovery of gas reserves during 1960 in the Indian states of Assam and Gujarat established the framework for India's natural gas business. However, during 1970 huge reserves of natural gas was discovered by ONGC in the South Basin areas. Until the 1970s, the production of petroleum and the search of new places for petroleum extraction were primarily limited to India's north-eastern states. However, the Indian petroleum sector had a turnaround when the Industrial Policy Resolution of 1956 was established, emphasizing the goal of expansion and promotion of businesses in India. There are different organizations dealing with sustainable assets yet at the same time the interest for oil and gas is on the ascent in India. Natural reserves are insufficient to meet the country's energy demand, hence India imports its oil from other countries about one third of its requirements [1] [2]. This article will explore and analyze various factors related to oil and gas industries which includes technological trends, innovations, corporate social responsibility, research and development, Covid-19 impact and its related economic impact.

\section{RELATED WORKS :}

The below table reviews the findings in the field of Oil and Gas Industries by different authors across the world. 
Table 1: Summarizes the findings by various authors

\begin{tabular}{|c|c|c|c|}
\hline $\begin{array}{l}\text { Sl. } \\
\text { No. }\end{array}$ & Area of Study & Focus & Reference \\
\hline 1 & $\begin{array}{l}\text { Block Chain } \\
\text { Technology }\end{array}$ & $\begin{array}{l}\text { Block chain Technology in the Oil } \\
\text { and Gas Industry: A Review of } \\
\text { Applications, Opportunities, } \\
\text { Challenges, and Risks }\end{array}$ & $\begin{array}{l}\text { Lu, H., Huang, K., Azimi, M., } \\
\text { \& Guo, L. (2019) [3] }\end{array}$ \\
\hline 2 & Digital Technology & $\begin{array}{l}\text { Overview of Oil and Gas Industry, } \\
\text { Research Trends, digital impacts, } \\
\text { Opportunities and Challenges }\end{array}$ & $\begin{array}{l}\text { Wanasinghe, T. R., } \\
\text { Wroblewski, L., Petersen, B. } \\
\text { K., Gosine, R. G., James, L. } \\
\text { A., de Silva, O., Mann, G. K. } \\
\text { I., \& Warrian, P. J. (2020) [4] }\end{array}$ \\
\hline 3 & $\begin{array}{l}\text { Innovation in Oil } \\
\text { and Gas industry } \\
\text { types }\end{array}$ & $\begin{array}{l}\text { How innovation and R\&D happen in } \\
\text { the upstream oil \& gas industry: } \\
\text { Insights from a global survey }\end{array}$ & Perrons, R. K. (2014) [5] \\
\hline 4 & $\begin{array}{l}\text { Oil and Gas } \\
\text { Industry service } \\
\text { strategy }\end{array}$ & $\begin{array}{l}\text { Implementation and execution of } \\
\text { industrial service strategy }\end{array}$ & $\begin{array}{l}\text { Kumar, R., Markeset, T., \& } \\
\text { Kumar, U. (2006) [6] }\end{array}$ \\
\hline 5 & Economic Impact & $\begin{array}{l}\text { The Impact of Oil Price Shocks on } \\
\text { the Economic Growth of Selected } \\
\text { MENA1 Countries }\end{array}$ & $\begin{array}{l}\text { Hakan Berument, M., Basak } \\
\text { Ceylan, N., \& Dogan, N. } \\
\text { (2010) [7] }\end{array}$ \\
\hline 6 & Economic Impact & $\begin{array}{l}\text { Economic Activities and Oil Price } \\
\text { Shocks in Indian Outlook: Direction } \\
\text { of Causality and Testing } \\
\text { Cointegration. }\end{array}$ & $\begin{array}{l}\text { Sharma, P., \& Shrivastava, A. } \\
\text { K. (2021). [8] }\end{array}$ \\
\hline 7 & $\begin{array}{l}\text { Corporate Social } \\
\text { Responsibilities }\end{array}$ & $\begin{array}{l}\text { Elements of CSR in India: exceptional } \\
\text { reference to oil and gas industry. }\end{array}$ & $\begin{array}{l}\text { Bhatt, S., \& Sharma, D. } \\
\text { (2019) [9] }\end{array}$ \\
\hline 8 & $\begin{array}{l}\text { Corporate Social } \\
\text { Responsibilities }\end{array}$ & $\begin{array}{l}\text { Institutionalization of Corporate } \\
\text { Social Responsibility (CSR) in India } \\
\text { and Its Effects on CSR Reporting: A } \\
\text { Case Study of the Petroleum and Gas } \\
\text { Industry. }\end{array}$ & Banerjee, S. (2019) [10] \\
\hline 9 & Covid-19 Impact & $\begin{array}{l}\text { Price impact on Crude Oil and } \\
\text { Natural Gas because of COVID19 }\end{array}$ & $\begin{array}{l}\text { Meher, B. K., Hawaldar, I. T., } \\
\text { Mohapatra, L., \& Sarea, A. } \\
\text { M. (2020) [11] }\end{array}$ \\
\hline 10 & Covid-19 Impact & $\begin{array}{l}\text { Digital change in the oil and gas area } \\
\text { during Coronavirus pandemic }\end{array}$ & $\begin{array}{l}\text { Hawash, B., Abuzawayda, Y. } \\
\text { I., Mokhtar, U. A., Yusof, Z. } \\
\text { M., \& Mukred, M. (2020) } \\
{[12]}\end{array}$ \\
\hline
\end{tabular}

\section{OBJECTIVES :}

(1) To analyze and understand the overview of Oil and Gas Industries.

(2) To assess and comprehend the various sorts of Oil and Gas Industries.

(3) To study and understand the Top 10 Oil and Gas industry trends and their innovations.

(4) To direct the SWOC investigation for the Oil and Gas Industries.

(5) To talk about the best 10 Oil and Gas organizations in India.

(6) To understand the Corporate Social Responsibility in these Industries.

(7) To report the Covid19 impact. 


\section{METHODOLOGY :}

The information presented and analyzed are primarily based on secondary data gathered from various online sources such as websites, internet blogs, books, journals, discussions, and articles.

\section{OVERVIEW OF OIL AND GAS INDUSTRY :}

Because India's economic growth is tied to its energy demand, demand for oil and gas will continue to rise, making this a lucrative investment area. To meet the rising demand, the government initiated a number of initiatives. In a number of areas, including as petroleum products, natural gas, and refineries, it has authorized 100 percent foreign direct investment. India has five private sector/joint venture refineries and eighteen public sector refineries with the largest being in Jamnagar, Vadinarand and Panipat, In India, Maharatna ONGC contributes approximately $71 \%$ of crude oil and natural gas production. Oil and gas are fundamental and imperative for worldwide financial development. Oil is derived from major nations such as the Russia, China, Canada and United States, Saudi Arabia [13] [14]. By 2022, the fossil fuel industry is predicted to draw huge investment in exploration and development. Detailed points mentioned below:

- The world's fastest expanding energy market and it is one of the India's major industrial sectors.

- The world's third-largest total primary energy usage.

- Primary user of crude oil in the world positioned on $3^{\text {rd }}$.

- The refinery is Asia's second-largest and the world's fourth-largest in terms of energy usage.

- A $\$ 143$ billion investment opportunity exists in the oil and gas sector.

- LPG coverage climbed high approx. 40 percent more from 2014 to 2020.

The below graph shows the India's Oil and Gas consumption. It is projected that 2021 consumption will raise and it will be similar to 2019 consumption.

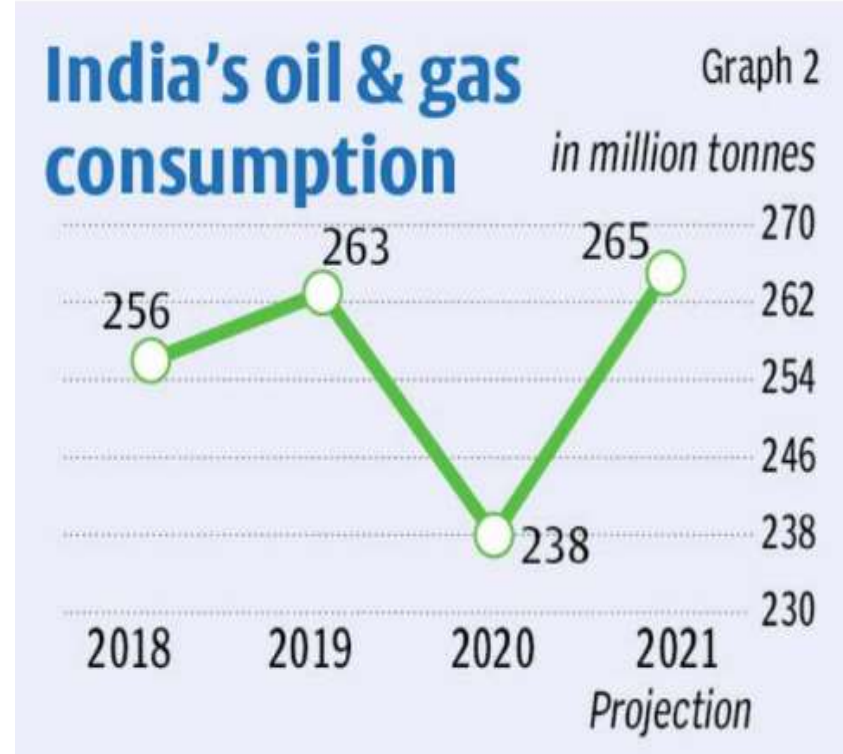

Source: the hindu business online

Fig. 1: India's Oil \& Gas Consumptions [15]

\section{OIL AND GAS INDUSTRY TYPES :}

Petroleum is classified as a fossil fuel and it can be extracted in two forms which are liquid and vapor. Liquid is crude oil, while vapor is gas. Three primary stages of harvesting are involved: downstream, midstream, and upstream [16].

\subsection{Upstream}

These exploration and production upstream companies look for and extract raw material resources. This category is generally distinguished by large investment capital, high risks, long duration and technological rigor. This firms actively looking for subterranean and undersea deposits of natural gas 
and crude oil. Companies that find, extract, or generate raw materials are upstream companies that are involved in oil and gas production. Geologists, service rig operators, geophysicists, scientists, engineering businesses and seismic and drilling contractors are among those working in the upstream sector. These individuals are capable of locating and estimating reserves before any drilling activity begins. Oil and Natural Gas Corporation, Reliance Industries Limited, Oil India Limited, BP PLC and Larsen \& Toubro Limited are among the leading participants in India's oil and gas upstream business.

\subsection{Midstream:}

The midstream segment is primarily concerned with everything needed to transport and store natural gas and oil. They contain all of the infrastructure required to carry these resources across great distances, such as tank trucks, transcontinental tankers, pumping stations and retail tank cars. Midstream operations treat the commodity by removing waste products or water, compress it, and prepare it for downstream markets. Indian Oil Corporation, Petronet LNG Limited, Adani Enterprises Ltd, Hindustan Petroleum Corporation Limited, Gail Limited and others are among the prominent firms. Trucking, shipping, raw material storage, and pipelines are typical characteristics of midstream firms. The midstream sector also involves product storage and any wholesale marketing initiatives. The last destination will be refineries, where the downstream procedures will commence.

\subsection{Downstream:}

Downstream is the last stage in the production process where flammable gas and unrefined petroleum are refined and items are brought to clients and end clients. Natural gas and Crude oil products are distributed and marketed by downstream industries. They are companies in charge of refining oil and gas and converting it into the various final goods that people rely on every day such as heating oil, jet fuel, asphalt and gasoline. Everyday products such as diesel, natural gas, gasoline, lubricants, heating oil, propane, insecticides and medicines are derived directly from downstream production. Long-chain hydrocarbons, which are found in oil and gas, are utilized to manufacture less apparent but equally crucial things such synthetic rubbers, preservatives, containers and plastics. In agribusiness and medication, downstream organizations assume a significant part. Bharat Petroleum Corporation Limited and Indian Oil Corporation Limited are a portion of the central participants.
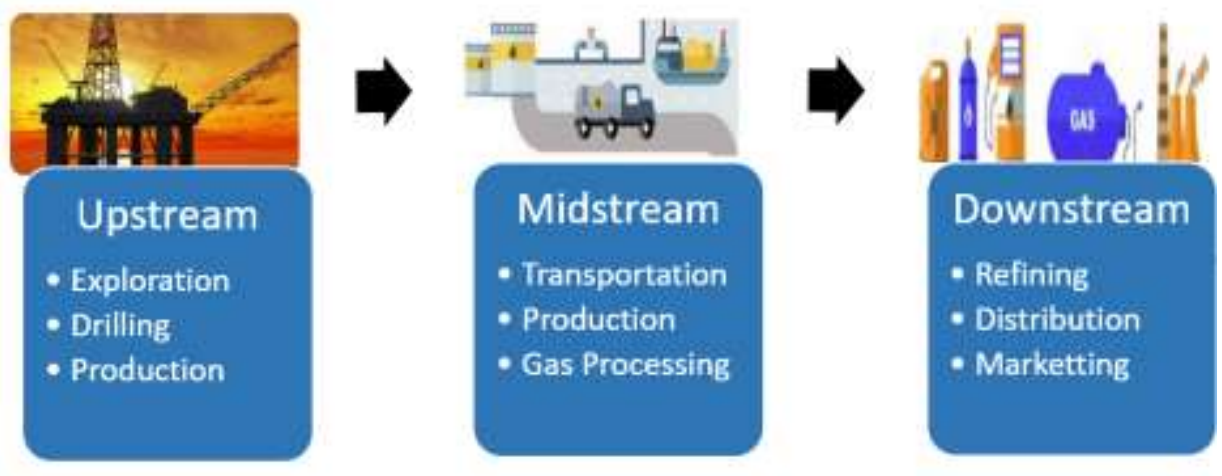

Fig. 2: Upstream, Midstream and Downstream Oil and Gas Industries [17]

Robust economic process of India has triggered more energy demand in India and it's projected to boost within the coming years. 
The below chart shows the oil demand of India as compared with other country example: China.

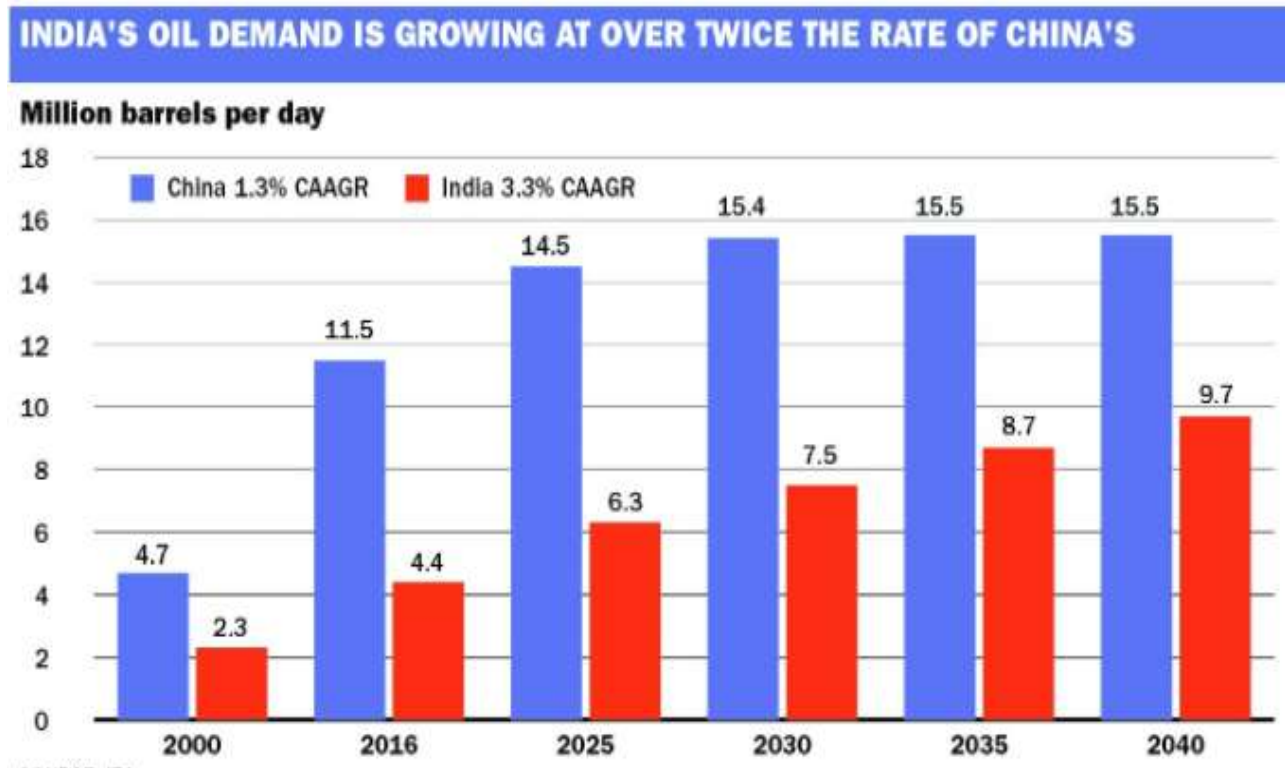

SOURCE: IEA

Fig. 3: India's oil demand in comparison to other Country [18]

\section{TOP 10 OIL \& GAS INDUSTRY TRENDS AND INNOVATIONS IN 2021 :}

The below figure shows the top 10 oil and gas industries innovations and trends in 2021. Oil and Gas Industries Identifies new opportunities and emerging technologies for gaining an advantage. As a result of technological advancements the efficiency of workers and operations are increased and costs are reduced. Big Data, Robotics and Artificial Intelligence will transform these industries. The COVID-19 outbreak has forced many businesses to reconsider their workplace and environmental policies.AI and IoT technologies improves processes in the Oil and Gas Industries. Inspection of both onshore and offshore equipment are done using drones and predictive maintenance. AI enables robotic applications in oil rigs and imaging processes in oil well refining. For improving worker's safety and for enabling remote operations augmented and virtual reality technologies are used. Block chain are also evaluated by these industries for using it in their operations. These Industries needs to adapt to these emerging new technologies and they need to address emerging challenges and move forward [19-23].

The below figure shows the top 10 trends in Oil and Gas Industry.

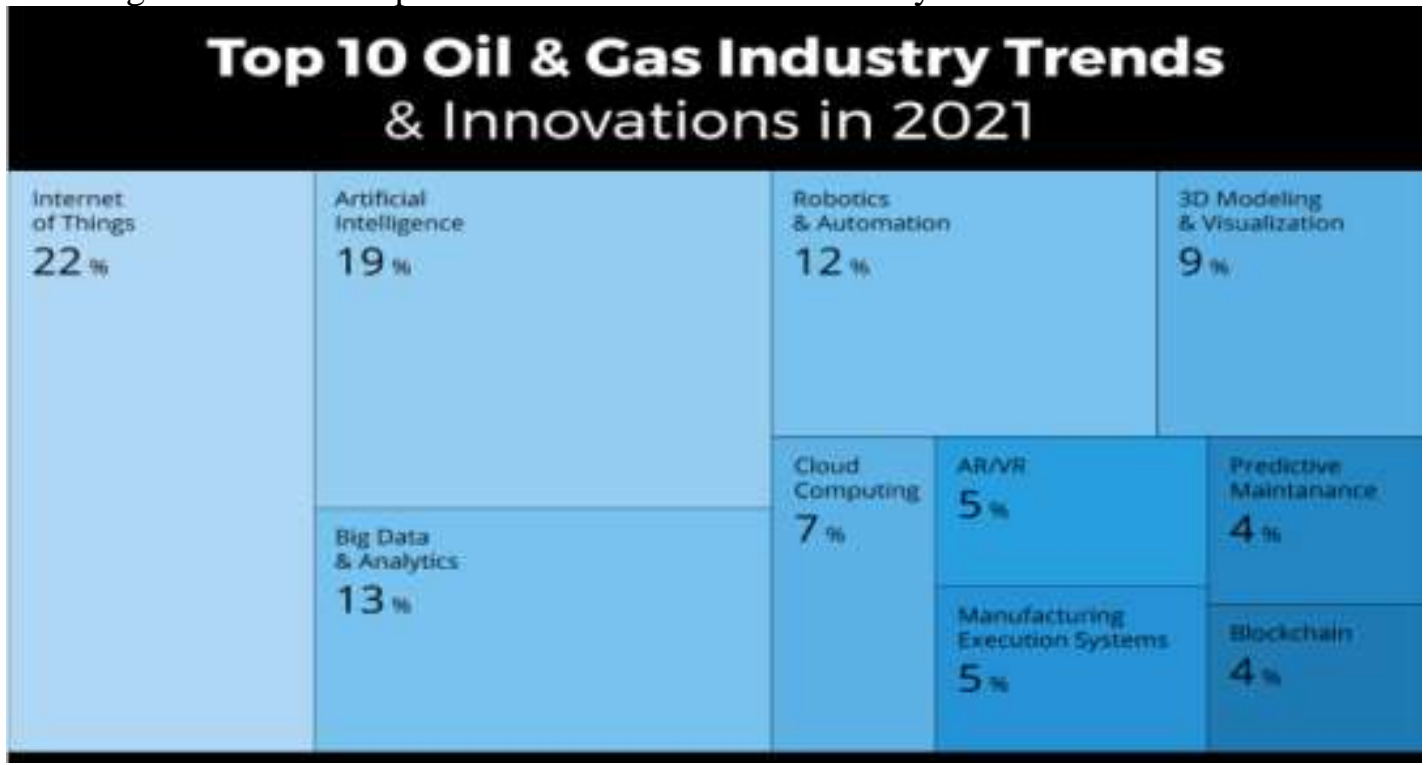

Fig. 4: Top 10 Oil \& Gas Industry Trends [24]

Source: Startups Insights 


\section{SWOC ANALYSIS :}

Strengths, Weaknesses, Opportunities, and Challenges (SWOC) analysis is a method of determining a company's strengths, weaknesses, opportunities, and challenges. Oil and Gas Industries will be able to map the present business environment and identify internal strategic aspects such as strengths and weaknesses, as well as external strategic factors such as opportunities and challenges, using this technique. Here we discuss in detail the Strength, Weaknesses, Opportunities, and Challenges of the Oil and gas industries.

\subsection{Strength:}

- Demand for petroleum-related products is high.

- As nation is developing extremely quick, oil and Gas request is exceptionally high.

- India's economic growth and energy demand are strongly intertwined.

- Natural resource is vast

- Crude oil and energy are consumed very high and India is one of the 10 top nation in consumption.

- Supplies to domestic market and exports are done easily by having refineries near to the distribution centers and ports.

- Export of petroleum products and crude oil imports happens easily because of vast coastline of India [25].

\subsection{Weakness:}

- The country's reliance on crude oil imports is high.

- The entry of the private and foreign oil and gas sectors is late.

- This industry involves very high cost and complex process of upstream, midstream and downstream for bringing the product to retail or to the market,

- Policies concerning safety

- Infrastructure features

- Oil price is not stable and continuously increasing

- Research and development should be integral part but it is found that these industries spends less money for innovating new features [26].

\subsection{Opportunities}

- The growth in cities and state are quick in terms of industrial enterprise and urbanization.

- More opportunities exists as there is more growth in the market in other field which directly and Indirectly impacts this industry.

- New oil fields have been discovered in West Bengal and East India, and there are still numerous natural reserves that have yet to be discovered.

- Country has wide growth in oil and gas trade

- Because of the huge population, there is a significant need on energy.

- Expanding infrastructure, particularly road and network infrastructure

- Interdependency between nation will result in more opportunities

- Investors from both international and Private sectors [27]

\subsection{Challenges}

- Operational safety parameters

- Small towns and rural regions faces challenges in terms of LPG coverage

- Governmental policies and procedures changes and interference in oil and gas industry always is high.

- LPG, fuel, and diesel consumption is extremely and unpredictably high.

- Instability in the Geopolitical System

- Tax rates are quite high, and they differ greatly between states.

- Within the oil and gas business both private and public sectors plays a major role and both sectors always have a high competition between them. 
- Challenge faced in India is we have lesser number of Oil and Gas Industries.

- In economics political, there is instability.

- Concerns about the environment.[28]

\section{TOP 10 OIL AND GAS INDUSTRIES :}

The below figure shows the list of India's Oil And Gas Companies.

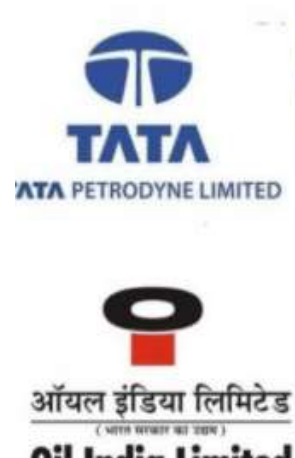

Oil India Limited
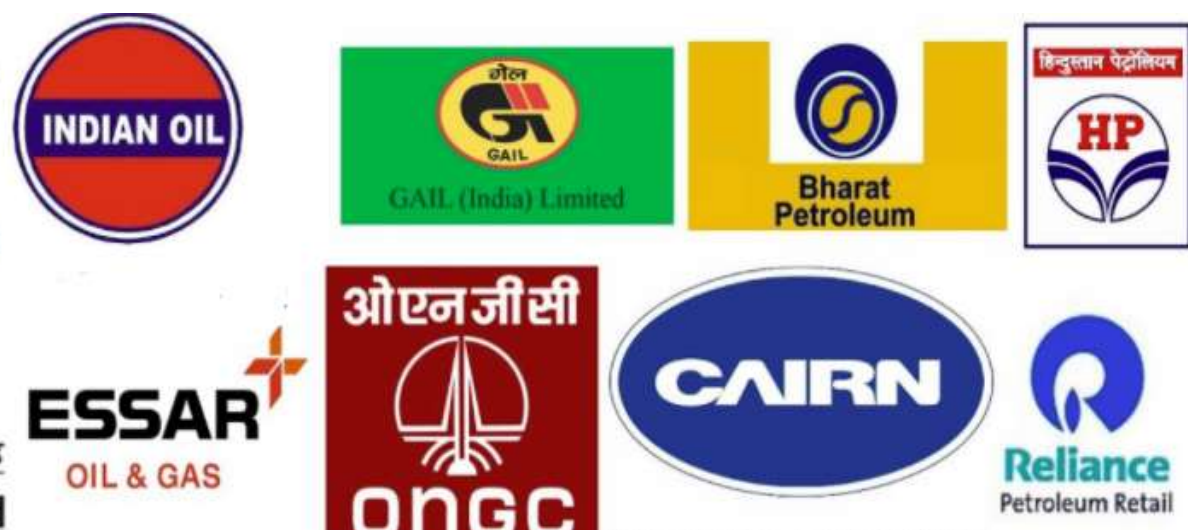

WE FUEL AMAZING

Fig. 5: Oil and Gas Industries [29]

Top 10 India's largest Oil and Gas Industries are mentioned in the below list. [30-31]

\subsection{Indian Oil Corporation:}

Indian Oil Corporation started in 1959 with its headquarters located in New Delhi and has its business around the entire globe. It is an Oil and gas company which operates the largest number of fuel stations all over India, estimating about 20,575 fuel stations. Auto Gas, Automotive Natural Gas, Xtra Premium, Xtra Mile, Automotive Premium Petrol, Automotive Premium Diesel, Indane Gas, Greases, Lubricants, Domestic and Industrial Gas are the other brands of this company and it is under public sector. It has subsidiaries in UAE, Mauritius and Sri Lanka.

\subsection{Bharat Petroleum:}

Bharat Petroleum Limited, centered in Mumbai, is one of the world's largest enterprises and public owned company. The corporation is controlled by the Indian government and operates refineries in India, including the Mumbai Refinery, Kochi Refineries, and Numaligarh Refinery. The company exports the highest quality Oil, Gas, and Petroleum Products to India and other countries following a rigorous manufacturing process.

\subsection{The Oil and Natural Gas Corporation Limited:}

This is Government owned companies of India which is under Ministry of Petroleum \& Natural Gas that produces crude oil and natural gas which contribute to $71 \%$ of domestic production. ONGC manages in all areas of Exploration and Production of oil \& gas and also services related to oil-fields. Pipelines operated by ONGC is approximately 11000 kilometers. ONGC headquarters are at Dehradun, Uttarkhand. The company employs about 33000 people and has a $\$ 6.50$ billion as a market capitalization.

\subsection{Reliance Petroleum Limited:}

With its headquarters in Ahmadabad, the Reliance Petroleum Limited Company has dominated the oil and gas production industry for decades. The organization is known for being the most adaptable and customer-focused in the country, if not the entire world. It also assists clients by offering options for locating the most cost-effective oil and gas capitals. Apart from supplying oil and other LPG items, it also has discussions for a large audience all around the world. It is part of a government-owned sector 
that employs over 10,000 people. The company's headquarters are in Ahmadabad, Gujarat, and it has a 670 million dollar turnover. It employs almost 10,000 people. Reliance Petroleum Limited benefits from a Singapore-based cooperation with Chevron India Holdings Pvt. Limited. The company's oil comes from the Jamnagar refinery, which is also the country's largest refinery.

\subsection{Essar Oil Limited:}

Essar Oil is an enterprise which is specialized in oil and gas exploration, production, purification, and marketing. With headquarters in Mumbai, it is one of the Essar Group's companies. Vadinar, Gujarat, is home to a major refinery, making it India's second largest non-state refiner. This corporation delivers excellent services to its clients, with a revenue of $\$ 9$ billion and over 75000 people.

\subsection{Cairn India:}

Cairn annual revenue is $\$ 3400$ million. It is one of the companies in the oil and natural gas sector, which employs approximately 2000 people. Because of its incredibly broad business coverage, this Oil and Gas Company stands out from the crowd. This is a public sector firm that produces products like oil, gas, and petroleum products for many organizations in India and abroad. Cairn India is a Vedanta Resources subsidiary and one of India's leading oil and gas producers.

\subsection{Gas Authority of India:}

The Gas Authority of India, or GAIL, is government oil and gas business in India. It employs about 4000 people and has an annual revenue of $\$ 8$ billion. It has a yearly turnover of more than ten billion dollars and is known in India as the most politically involved. With its headquarters in New Delhi, it is known for supplying reasonably priced oil, gas, and petroleum products to the entire world. It is essentially a government-owned corporation with a workforce of over 4,700 people. The Government of India awarded the corporation Maharatna status in 2013.

\subsection{Hindustan Petroleum Corporation:}

This Oil and Gas Company is a Navratna certified Public Sector Undertaking of the Indian Government that is involved in the refining and sale of petroleum-based goods. It has multiple refineries and large network of gas stations. It is headquartered in Mumbai, Maharashtra. Oil, natural gas, petroleum, lubricant, petrochemicals, and other products are among the company's offerings. It has a strong marketing infrastructure and over $20 \%$ marketing share among PSUs in the country.

\subsection{Oil India Ltd:}

The main product produced by this industry are Petrochemical, petroleum and natural gas and it is Government owned and headquartered in Assam. This company has its crude oil production and also its natural gas production majority in the North east. They have oil production in Rajasthan and in the onshore areas of Ganga valley and Mahanadi.

\subsection{Tata PETRODYNE Limited:}

Tata Petrodyne is the privately owned Oil and Gas Company under the subsidiaries of Tata Group with 200 Billion Dollars as yearly turnover. It has headquartered in Mumbai. Seven offshore and onshore sites exists in India. There was a drastic reduction in fuel demand during 2020 because of coronavirus pandemics lockdowns. As a result, for all major oil and Gas industries revenues decline drastically.

The below chart shows the top oil and gas industries revenue details in billion U.S dollars as of 2021 . 


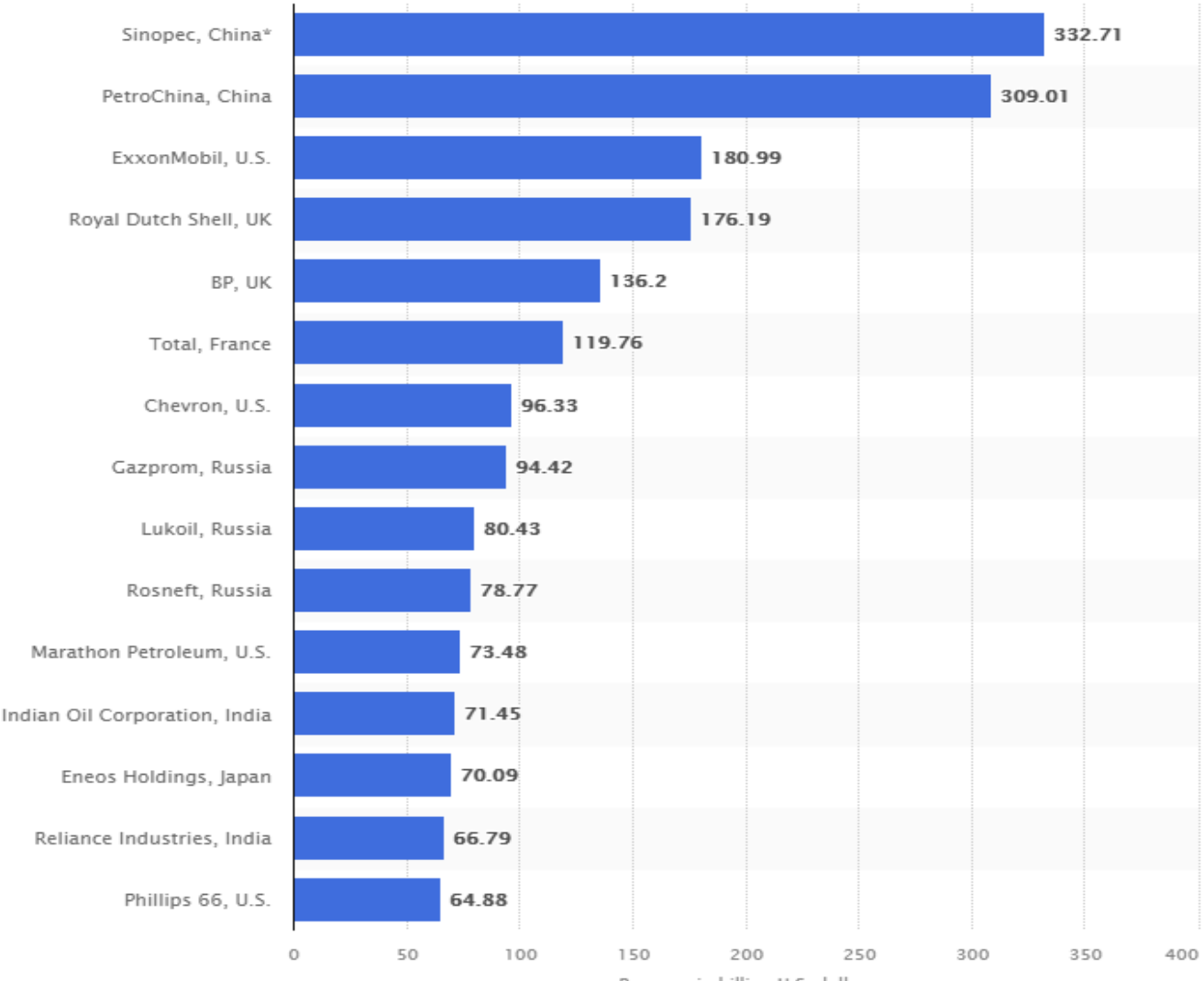

Fig. 6: Global revenue of top oil and gas companies in billions of dollars as of 2021 [32]

Source: Statista

The Production of petroleum products from these oil and gas industries and Consumption of these petroleum products are shown in the below table:

Table 2: Petroleum products production and consumption (2018-2020) [33]

\begin{tabular}{|c|c|c|c|c|c|c|c|c|c|c|c|c|}
\hline \multicolumn{13}{|c|}{ 12. Production and consumption of petroleum products (Million Metric Tonnes) } \\
\hline \multirow{2}{*}{ Products } & \multicolumn{2}{|c|}{ 2018-19 } & \multicolumn{2}{|c|}{ 2019-20 } & \multicolumn{2}{|c|}{ December 2019} & \multicolumn{2}{|c|}{ December $2020(P)$} & \multicolumn{2}{|c|}{ Apr-Dec 2019} & \multicolumn{2}{|c|}{ Apr-Dec 2020 (P) } \\
\hline & Prod & Cons & Prod & Cons & Prod & Cons & Prod & Cons & Prod & Cons & Prod & Cons \\
\hline LPG & 12.8 & 24.9 & 12.8 & 26.3 & 1.1 & 2.4 & 1.1 & 2.5 & 9.5 & 19.5 & 8.9 & 20.6 \\
\hline MS & 38.0 & 28.3 & 38.6 & 30.0 & 3.2 & 2.5 & 3.3 & 2.7 & 29.0 & 22.9 & 25.8 & 20.1 \\
\hline NAPHTHA & 19.6 & 14.1 & 20.6 & 14.3 & 1.9 & 1.3 & 1.6 & 1.2 & 14.9 & 10.3 & 14.0 & 10.5 \\
\hline ATF & 15.5 & 8.3 & 15.2 & 8.0 & 1.3 & 0.7 & 0.7 & 0.4 & 11.5 & 6.1 & 4.7 & 2.4 \\
\hline SKO & 4.1 & 3.5 & 3.2 & 2.4 & 0.2 & 0.2 & 0.2 & 0.1 & 2.3 & 1.9 & 1.8 & 1.4 \\
\hline HSD & 110.6 & 83.5 & 111.1 & 82.6 & 9.2 & 7.4 & 9.5 & 7.2 & 83.1 & 62.8 & 72.7 & 52.1 \\
\hline LDO & 0.7 & 0.6 & 0.6 & 0.6 & 0.0 & 0.0 & 0.1 & 0.1 & 0.5 & 0.5 & 0.5 & 0.6 \\
\hline LUBES & 0.9 & 3.7 & 0.9 & 3.8 & 0.1 & 0.3 & 0.1 & 0.3 & 0.7 & 2.9 & 0.7 & 2.5 \\
\hline FO/LSHS & 10.0 & 6.6 & 9.3 & 6.3 & 0.6 & 0.6 & 0.6 & 0.6 & 7.1 & 4.6 & 6.4 & 4.4 \\
\hline BITUMEN & 5.6 & 6.7 & 4.9 & 6.7 & 0.4 & 0.6 & 0.6 & 0.8 & 3.4 & 4.6 & 3.1 & 4.8 \\
\hline PET COKE & 13.7 & 21.3 & 14.6 & 21.7 & 1.4 & 2.0 & 1.1 & 1.6 & 10.8 & 16.7 & 8.8 & 13.5 \\
\hline OTHERS & 31.0 & 11.7 & 31.0 & 11.4 & 2.8 & 1.0 & 2.6 & 1.0 & 22.8 & 8.7 & 21.8 & 7.8 \\
\hline ALL INDIA & 262.4 & 213.2 & 262.9 & 214.1 & 22.1 & 18.9 & 21.5 & 18.6 & 195.5 & 161.3 & 169.1 & 140.6 \\
\hline Growth (\%) & $3.2 \%$ & $3.4 \%$ & $0.2 \%$ & $0.4 \%$ & $3.0 \%$ & $0.7 \%$ & $-2.8 \%$ & $-1.8 \%$ & $-0.6 \%$ & $2.3 \%$ & $-13.5 \%$ & $-12.8 \%$ \\
\hline
\end{tabular}

Note: Prod - Production; Cons - Consumption 
The below chart shows the details of Production of petroleum and crude oil products from Oil and Gas Industries of India. Also the consumption of petroleum products against the production shown below:

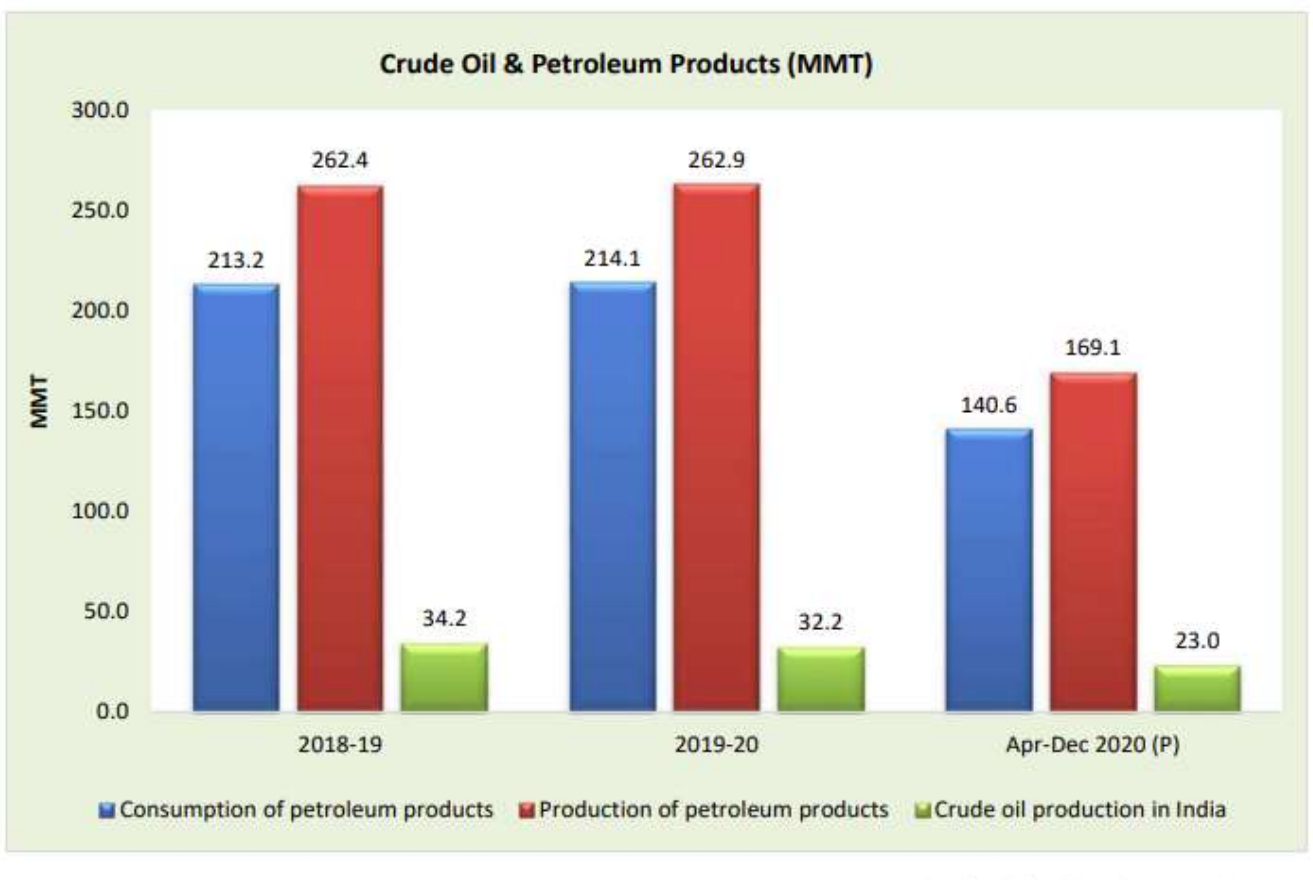

Snapshot of India's Oil \& Gas data - December, 2020

Fig. 7: Production/Consumption of petroleum products Vs Production of Crude oil [33]

\section{CORPORATE SOCIAL RESPONSIBILITY :}

Corporate Social Responsibility of industries is that it should concentrate towards society well-being and also contributes towards social and environment concerns which will bring positive transformation to the society and people. Every oil and gas industry should continuously work towards corporate social responsibility and engage in political, social, economic, technological, legal, and environmental areas. Oil and GAS industries is continuously working on many CSR projects and programs under problem areas of society which includes Sanitation, Healthcare, Drinking water, Capacity Building \& Empowerment of Women, Environment, Education, Skill Development, Rural Sports, Sustainable Livelihood Generation and Rural Development by improving Rural Infrastructure [34].

Industries like ONCG has implemented more than 4000 projects and has allocated and utilized 100\% of CSR budget which is approximately Rs.500 Crore each year. Industries like ONGC are committed by giving back to the society in equal measure. As per mandate from Government, ONGC has spent $33 \%$ of its CSR budget on Swachh Bharat projects and remaining budget on Education and Health Care. Indian Oil Company is also doing various projects as a part of Corporate Social Responsibility activities. Indian Oil Company has worked on projects like establishing toilets in the schools, performing cleanliness drives in the retail outlets of oil and gas. It has also three waste-to-energy converting plants for processing the Solid waste in the city. It has also provided $12 \mathrm{RO}$ drinking water unit as a part of CSR projects. As a part of Swachh Bharat Abhiyan, Indian Oil Company has constructed toilets in Mysore and also it has donated vehicle which has a desilting machine which cleans underground drainage in Mysore. The below chart shows the CSR spent by Indian Oil Corporation [35] [36] [37].

The below chart shows the CSR spent in Indian Oil Corporation. 


\section{International Journal of Case Studies in Business, IT, and Education $\quad$ SRINIVAS (IJCSBE), ISSN: 2581-6942, Vol. 6, No. 1, February 2022

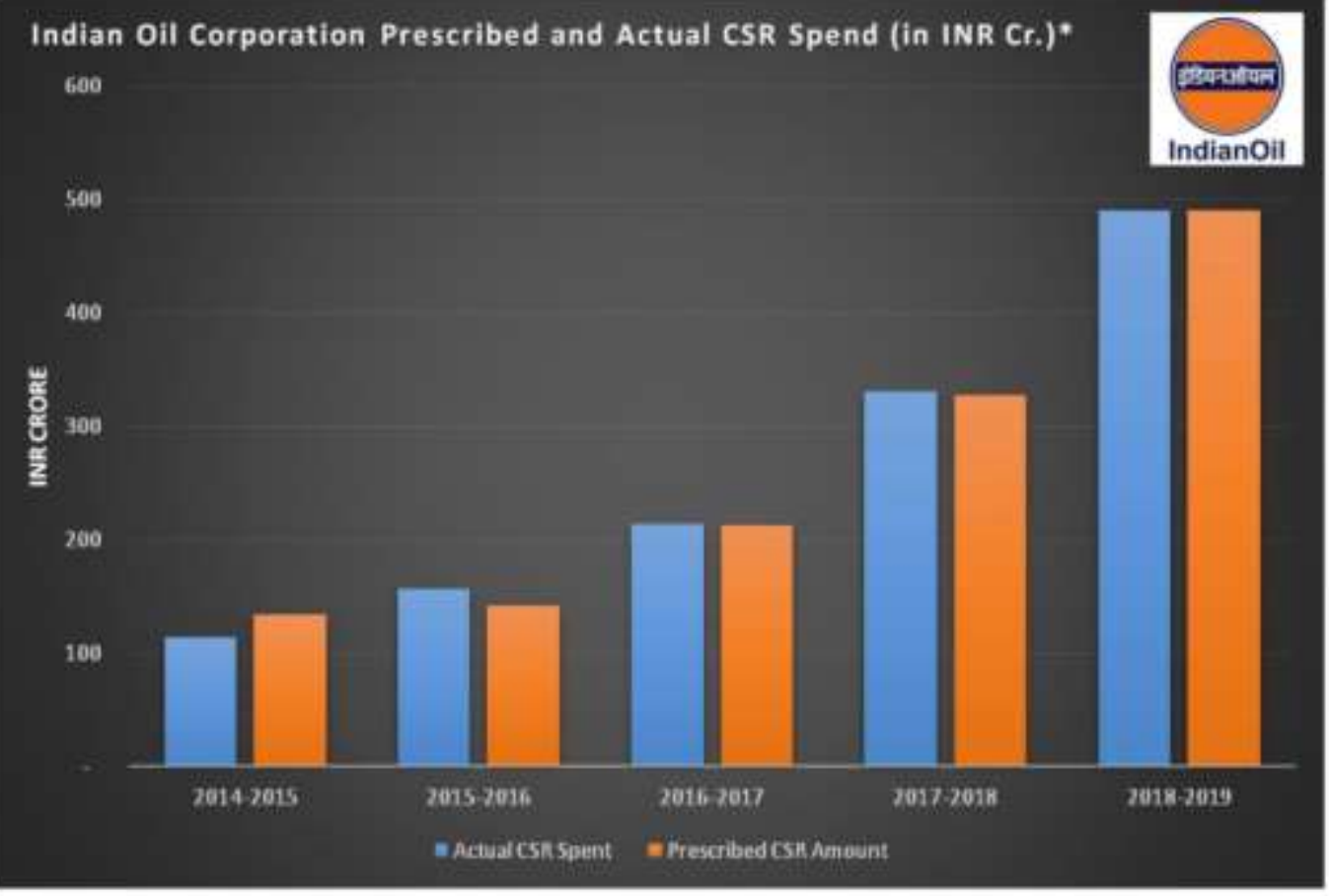

Intian Dar CSR apent for the last 5 venct

Fig. 8: CSR spent (Actual Vs Prescribed) in Indian Oil Corporation (in INR Cr.) [38]

\section{COVID-19 IMPACT :}

Oil and Gas industries were affected by both oil price drop and Covid-19 impact. Imbalance occurred between supply and demand as the production in industries were slow because of pandemic and travel restriction in the countries. Oil and Gas companies continues their production and it resulted globally that crude oil market has crude oil more than it can accommodate and store [39] [40]. This is due to an overstock produced by a market share battle between Russia and OPEC.As the mobility and transportation are hit, the demand of gasoline and diesel also went down [41]. Industrial activity and their operations slowed down as the employees were affected by Covid-19.In 2020, when the first wave was hit and when there was a nationwide lockdown in the entire country the gas consumption dropped by $40 \%$. City gas distribution dropped approximately by $25 \%$ as infections was very high in the main India cities like Mumbai, New Delhi and Kolkata. The below chart shows how the segment hit worst because of Covid-19.

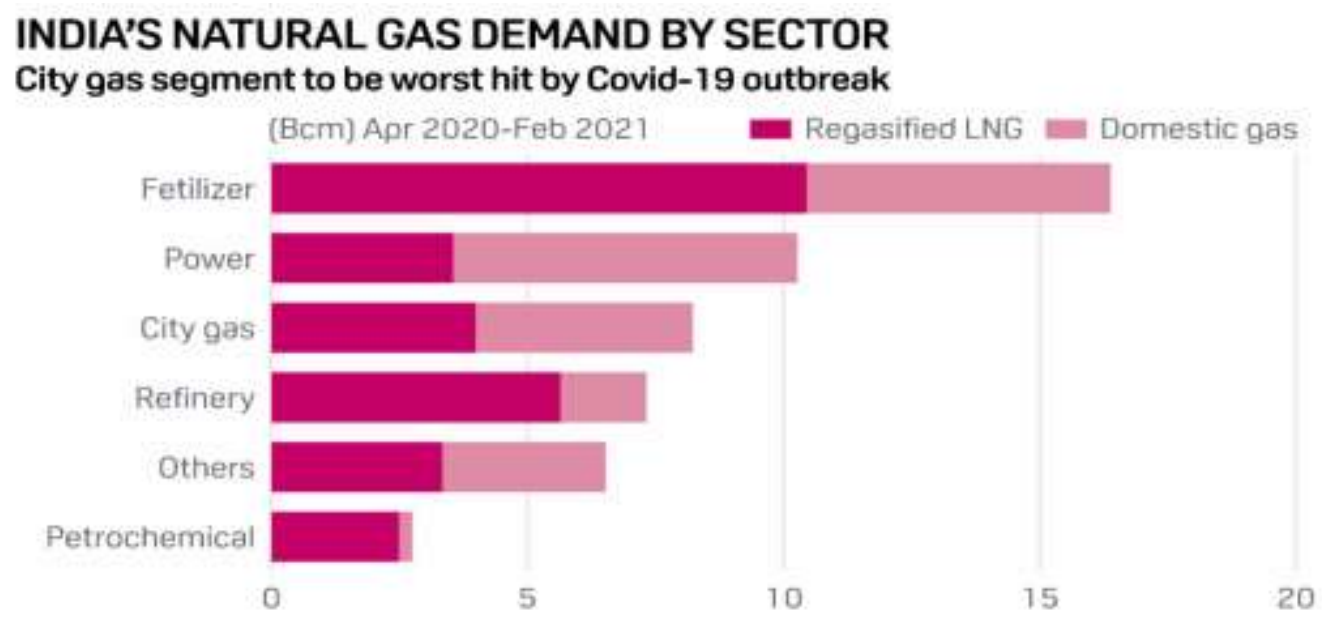

Source: Indian oil ministry

Fig. 9: India’s Natural Gas demand by Sector [42] 
Lower oil prices, impact of economic because of the Covid-19 crisis, oversupply from oil and gas industry lead to severe impact in many industries. It is unlikely that oil and gas industry will recover to normal like before. If this prolongs and oil prices will be continuously low, investors will divert and invest in different business model as this business looks more risky and not commercially attractive [43].

\section{RECOMMENDATIONS AND SUGGESTIONS :}

India's growth is coupled to its energy demand, the demand for oil and gas can raise more that makes this sector a lovely sector for investment. Downstream, Midstream, and Upstream are the three primary stages of harvesting where currently industries are trying to use innovative technologies and also working on new technologies that will reduce or avoid risky manual tasks done by human beings. Top 10 India's largest Oil and Gas Industries are closely working to bring innovative technologies and also provide more job opportunities. These Industries also concentrates more on CSR and also towards social and environment attributes so it brings positive transformation to the society and people. Covid-19 has created impact globally in the oil and gas industry and the Industrial activity and their operations slowed down as the employees were affected by Covid- 19 .

Oil and Gas Industries should invest in projects related to renewable sources and non-carbon energy as India's energy requirement is expected to be doubled and raise at the fastest pace in the world. Electric and battery operated vehicles reduces carbon emission, so considering environmental impact this should be introduced more into the market with affordable cost.

Oil and Gas Industries should use new technologies like Internet of things, drones, big data analytics, robotics, cloud computing and cybersecurity and artificial intelligence to establish safer environmental conditions. Also these technologies can be used in upstream, downstream and midstream of Oil and Gas industries to increase the efficiency and performance of the industries [44]. It is suggested that Oil and Gas Industries should increase the Research and Development activities in the area of Oil and Gas Extraction Activities using new technologies and also these technologies needs to be explored and innovated to provide safety in multiple activities performed during Oil exploration and extraction [45].

\section{CONCLUSION :}

Oil and Gas Industries are crucial in the modern economy as the petroleum industry is one of the India's core industries, and it has a significant impact on decision-making in the critical sectors of the India's economy. These enterprises assumes a basic part in the worldwide economy and India's financial development is connected with oil and gas interest. Energy demand is growing every day so the investment in this sector is also continuously growing every day. More projects and studies needs to be performed associated with renewable energy, also this needs to be mandates and it should be performed as an opportunity to non-renewable energy. Oil and Gas Industries helps for the boom of the financial system and additionally it gives employment possibilities to the people. Oil and Gas Industries should invest in projects which are alternative to Oil and Gas such as projects related to renewable sources and non-carbon energy. Oil and Gas Industries are expected to invest in the recent technologies in their various projects and activities to achieve automation in the process, safer environment, efficiency and performance.

\section{REFERENCES :}

[1] Muspratt, A. (2019, May 1). Introduction to Oil and Gas Industry. Oil \& Gas IQ. Retrieved August 20, 2021, from https://www.oilandgasiq.com/strategy-management-and-information/articles/oilgas-industry-an-introduction

[2] Aithal, P. S. (2017). Company Analysis - The Beginning Step for Scholarly Research. International Journal of Case Studies in Business, IT, and Education, 1(1), 1-18. Google Scholar X CrossRef $x^{\nearrow}$

[3] Lu, H., Huang, K., Azimi, M., \& Guo, L. (2019). Blockchain Technology in the Oil and Gas Industry: A Review of Applications, Opportunities, Challenges, and Risks. IEEE Access, 7(1), 119.

$\underline{\text { Google Scholar } x^{7} \quad \underline{\text { CrossRef }} x^{7}}$ 
[4] Wanasinghe, T. R., Wroblewski, L., Petersen, B. K., Gosine, R. G., James, L. A., de Silva, O., Mann, G. K. I., \& Warrian, P. J. (2020). Digital Twin for the Oil and Gas Industry: Overview, Research Trends, Opportunities, and Challenges. IEEE Access, 8(1), 1-23.

$\underline{\text { Google Scholar } x^{\top} \quad \underline{\text { CrossRef }} x^{\top}}$

[5] Perrons, R. K. (2014). How innovation and R\&D happen in the upstream oil \& gas industry: Insights from a global survey. Journal of Petroleum Science and Engineering, 124(1), 1-49.

Google Scholar $\chi^{\top} \quad$ CrossRef $x^{\top}$

[6] Kumar, R., Markeset, T., \& Kumar, U. (2006). Implementation and execution of industrial service strategy. Journal of Quality in Maintenance Engineering, 12(2), 1-15.

Google Scholar $X^{\top} \quad \underline{\text { CrossRef }} x^{\top}$

[7] Hakan Berument, M., Basak Ceylan, N., \& Dogan, N. (2010). The Impact of Oil Price Shocks on the Economic Growth of Selected MENA1 Countries. The Energy Journal, 31(1), 1-8.

$\underline{\text { Google Scholar }{ }^{\top} \quad \text { CrossRef }{ }^{7}}$

[8] Sharma, P., \& Shrivastava, A. K. (2021). Economic Activities and Oil Price Shocks in Indian Outlook: Direction of Causality and Testing Cointegration. Global Business Review, 1(1),1-20.

Google Scholar ${ }^{7} \quad \underline{\text { CrossRef }} x^{7}$

[9] Bhatt, S., \& Sharma, D. (2019). Dynamics of CSR in India: special reference to oil and gas industry. International Journal of Engineering and Advanced Technology, 8(5), 339-343.

Google Scholar’ CrossRef $x^{7}$

[10] Banerjee, S. (2019). Institutionalization of Corporate Social Responsibility (CSR) in India and Its Effects on CSR Reporting: A Case Study of the Petroleum and Gas Industry. Mandated Corporate Social Responsibility, 1(1), 141-157.

Google Scholar ${ }^{7} \quad \underline{\text { CrossRef }} x^{7}$

[11] Meher, B. K., Hawaldar, I. T., Mohapatra, L., \& Sarea, A. M. (2020). The Impact of Covid-19 On Price Volatility Of Crude Oil And Natural Gas Listed On Multi Commodity Exchange of India. International Journal of Energy Economics and Policy, 10(5), 422-431.

Google Scholar $x^{\top} \quad$ CrossRef $x^{\top}$

[12] Hawash, B., Abuzawayda, Y. I., Mokhtar, U. A., Yusof, Z. M., \& Mukred, M. (2020). Digital Transformation In The Oil And Gas Sector During Covid-19 Pandemic. International Journal of Management, 11(12),1-11.

Google Scholar $x^{\top} \quad$ CrossRef $x^{7}$

[13] Aithal, P. S. (2017). Industry Analysis - The First Step in Business Management Scholarly Research. International Journal of Case Studies in Business, IT, and Education, 1(1), 1-13. Google Scholar $x^{\top} \quad$ CrossRef $x^{\top}$

[14] Oil \& Gas Industry in India. (n.d.). https://www.Ibef.Org/Industry/Oil-Gas-India.Aspx/. Retrieved July 10, 2021, from https://www.ibef.org/industry/oil-gas-india.aspx/

[15] The Hindu BusinessLine. (n.d.). Business Financial, Economy, Market, Stock - News \& Updates. @ businessline. Retrieved September 3, 2021, from https://www.thehindubusinessline.com

[16] Petro Industry News. (n.d.). Upstream, Midstream and Downstream - Understanding the Three Petroleum Markets. Petro Online. Retrieved July 25, 2021, from https://www.petroonline.com/news/fuel-for-thought/13/breaking-news/upstream-midstream-and-downstreamndash-understanding-the-three-petroleum-markets/32165

[17] Research Guides: Oil and Gas Industry: A Research Guide: Downstream: Refining and Marketing. (n.d.). Https://Guides.Loc.Gov/Oil-and-Gas-Industry/. Retrieved August 9, 2021, from Https://Guides.Loc.Gov/Oil-and-Gas-Industry/Downstream

[18] India to become an engine of crude oil demand growth. (n.d.). http://www.Bunkerportsnews.Com/. Retrieved July

10 ,

2021, from 
http://www.bunkerportsnews.com/News.aspx?ElementId=1ebdc12c-7a50-4b1d-9c22824746d709a9

[19] 10 Oil And Gas Trends To Watch In 2021. (n.d.). Gartner. Retrieved September 10, 2021, from https://www.gartner.com/smarterwithgartner/10-oil-and-gas-trends-to-watch-in-2021

[20] Baurina, S. B., Garnova, V. Y., \& Tchaikovskaya, L. A. (2020). Modern Technological Priorities of the Gas Industry Innovative Development. IOP Conference Series: Materials Science and Engineering, 753(5), 3-4.

Google Scholar $x^{7}$

CrossRef $\chi^{7}$

[21] Mohammadpoor, M., \& Torabi, F. (2020). Big Data analytics in oil and gas industry: An emerging trend. Petroleum, 6(4), 321-328.

Google Scholar $x^{\top} \quad$ CrossRef ${ }^{\top}$

[22] Beckwith, R. (2011). Managing Big Data: Cloud Computing and Co-Location Centers. Journal of Petroleum Technology, 63(10), 42-45.

Google Scholar $x^{\top} \quad$ CrossRef $x^{7}$

[23] Tran Vu Tung, Tran Ngoc Trung, Ngo Huu Hai, \& Nguyen Thanh Tinh. (2020). Digital transformation in oil and gas companies - A case study of Bien Dong POC. Petrovietnam Journal, 10(1), 67-78.

Google Scholar $\chi^{7} \quad$ CrossRef $\chi^{7}$

[24] Top 10 Oil \& Gas Industry Trends \& Innovations in 2021. StartUs Insights. Retrieved September 19, 2021, from https://www.startus-insights.com/innovators-guide/top-10-oil-gas-industry-trendsinnovations-in-2021/

[25] Hajizadeh, Y. (2019). Machine learning in oil and gas; a SWOT analysis approach. Journal of Petroleum Science and Engineering, 176(1), 661-663.

Google Scholar $x^{\top} \quad$ CrossRef $x^{\top}$

[26] Bhasin, H. (2019, May 13). SWOT Analysis of ONGC. Marketing91. Retrieved September 29, 2021, from https://www.marketing91.com/swot-analysis-of-ongc/

[27] Shastri, A. (n.d.). SWOT Analysis \& Marketing Strategy of Indian Oil Corporation. IIDE. Retrieved October 2, 2021, from https://iide.co/case-studies/marketing-strategy-of-indian-oilcorporation/

[28] Aithal, P. S. and Kumar, P. M. (2015, July 10) Applying SWOC Analysis to an Institution of Higher Education. International Journal of Management, IT and Engineering, 5(7), 1-17.

Google Scholar ${ }^{\top} \quad$ CrossRef $x^{\top}$

[29] Giri, A. (2021, October 20). Top 10 Oil and Gas Companies in India 2021. Myblogindia. Retrieved October 24, 2021, from https://myblogindia.com/top-10-oil-and-gas-companies-in-india/

[30] K, K. (2019, June 27). Top 10 Largest Oil And Gas Companies in India. WalkThroughIndia. Retrieved September 19, 2021, from http://www.walkthroughindia.com/industry/top-10-largestoil-and-gas-companies-in-india/

[31] Admin, B. (2021, September 8). Top 10 Oil and Gas Companies in India - Learning Center Fundoodata.co. Learning Center - Fundoodata.Com. Retrieved August 21, 2021, from https://www.fundoodata.com/learning-center/top-10-oil-gas-companies-india/

[32] Leading global oil and gas producers based on revenue 2021. (2021, June 8). Statista. Retrieved October 11, 2021, from https://www.statista.com/statistics/272710/top-10-oil-and-gas-companiesworldwide-based-on-revenue/

[33] Home: Petroleum Planning \& Analysis Cell. (n.d.). https://www.Ppac.Gov.In/. Retrieved October 2, 2021, from https://www.ppac.gov.in/WriteReadData/Reports/ 202106180438204451952SnapshotofIndiasOilandGasdataMay2021.pdf

[34] India Oil and Gas Upstream Market | 2021 - 26 | Industry Share, Size, Growth - Mordor 
Intelligence. (n.d.). https://www.mordorintelligence.Com/Industry-Reports/. Retrieved September 4, 2021, from https://www.mordorintelligence.com/industry-reports/india-oil-and-gas-upstreammarket

[35] Koolwal, N., \& Khandelwal, S. (2019). Corporate Social Responsibility (CSR) Implementation in Oil \& Gas Industry: Challenges and Solutions. SSRN Electronic Journal. Published, 1(1), 1-8.

Google Scholar $\chi^{\top} \quad \underline{\text { CrossRef }}{ }^{7}$

[36] Frynas, J. G. (2009). Corporate social responsibility in the oil and gas sector. The Journal of World Energy Law \& Business, 2(3), 178-195.

Google Scholar $x^{7} \quad$ CrossRef $x^{\top}$

[37] CSR Activities of Indian Oil Corporation Limited | Green Initiatives | environmental and healthcare projects | educational programmes. (n.d.). http://www.Csrworld.Net/. Retrieved August 23, 2021, from http://www.csrworld.net/csr-activities-of-indian-oil-corporation-limited.asp

[38] Fernandes, K. (2021, February 4). Indian Oil CSR is Making India Future-Ready. The CSR Journal. Retrieved September 16, 2021, from https://thecsrjournal.in/indian-oil-csr-report-indiapsu/

[39] Raj, K., \& Aithal, P. S. (2020). The Post COVID-19 World: Efforts Needed to Build Back a More Resilient Society. International Journal of Case Studies in Business, IT, ' ${ }^{\prime}$ and Education (IJCSBE), 4(1), 88-93.

Google Scholar $x^{\top}$

\section{CrossRef $x^{7}$}

[40] Petroleum: Surviving in the post-COVID-19 era | Arthur D. Little. (n.d.). Https://Www.Adlittle.Com/. Retrieved September 11, 2021, from https://www.adlittle.com:443/en/insights/prism/petroleum-surviving-in-the-post-covid-19-era

[41] Albulescu, C. (2020). Coronavirus and Oil Price Crash. SSRN Electronic Journal, 1(1), 4-11. Google Scholar $x^{7} \quad$ CrossRef $x^{7}$

[42] Yep, E. S. A. A. R. D. (2021, April 29). S\&P Global Platts. Https://www.Spglobal.Com. Retrieved October 17, 2021, from https://www.spglobal.com/platts/en/market-insights/latest-news/naturalgas/042921-indias-city-gas-demand-may-drop-by-25-30-as-covid-19-cripples-key-states

[43] Oil \& Gas. (n.d.-b). https://www.Mckinsey.Com/Industries/Oil-and-Gas/Our-Insights/Oil-andGas-after-Covid-19-the-Day-of-Reckoning-or-a-New-Age-of-Opportunity. Retrieved August 11, 2021, from https://www.mckinsey.com/industries/oil-and-gas/our-insights

[44] Paes, H. B. D. C. (2012). Investigation Into Stakeholders' Influence on The Environmental Strategies of Oil Companies - A Case Study of Petrobras. Online Journal of Communication and Media Technologies, 2(3), 3-18.

Google Scholar Х $\quad$ CrossRef $\chi^{\lambda}$

[45] World Future Energy Summit | ADNEC, Abu Dhabi. (n.d.). https://Www.Worldfutureenergysummit.Com/. Retrieved September 19, 2021, from https://www.worldfutureenergysummit.com/en-gb/future-insights-blog/8-ways-the-oil-and-gasindustry-is-making-better-use-of-sustainable-technologies.html 